\title{
THE CORRELATION BETWEEN VOCABULARY MASTERY AND READING COMPREHENSION
}

\author{
Hasanul Bishry \\ Sekolah Tinggi Ilmu Ekonomi Riau \\ email: hasanulbishry@lecturer.stieriau-akbar.ac.id
}

\begin{abstract}
Abstrak: Penelitian ini bertujuan untuk mengukur apakah ada korelasi antara penguasaan kosakata dan kemampuan membaca mahasiswa di Sekolah Tinggi Ilmu Ekonomi Riau pada Program Studi keuangan Perbankan dan Akuntansi. Adapun responden penelitian ini sebnyak 26 orang. Penelitian ini menggunakan sensus sampling dimana semua mahasiswa Program Studi Keuangan dan Perbankan serta Akuntansi menjadi sample. Teknik pengambilan data menggunakan instrument tes. Tes diberikan kepada mahasiswa untuk mengukur kosa kata dan kemampuan membaca. Analisis penelitian ini menggunakan program SPSS dalam menghitung hasil. Adapun hasil yang diperoleh dari penelitian ini adalah: Penguasaan kosakata mahasiswa sangat baik dan kemampuan membaca mahasiswa berada di kategori baik. Tetapi dari hasil perhitungan menunjukkan bahwa tidak ada korelasi antara penguasaan kosakata terhadap kemampuan membaca mahasiswa. Dari hasil ini dapat disimpulkan bahwa ada factor lain yang mempengaruhi kemampuan membaca mahasiswa
\end{abstract}

Kata Kunci: Penguasaan Kosakata, Kemampuan Membaca

\begin{abstract}
The aim of this study is to describe the correlation between vocabulary mastery and reading ability of the Banking and Accounting Financial department students in the Riau Economics College. The respondents of this study were 26 people. This study used a sampling census where all students of the Banking and Accounting Financial department were sampled. The data collection technique used a test instrument. Tests are given to students to measure vocabulary and reading skills. Analysis of this study used the SPSS program. The results of this study are: Students' Vocabulary Mastery is very good and the student's reading ability is in the good category. But the results of the analyses show there is no correlation between vocabulary mastery and reading skills. From these results it can be concluded that there are other factors that influence students' reading ability
\end{abstract}

Keyword: Vocabulary Mastery, Reading Ability 


\section{INTRODUCTION}

In teaching and learning process, reading plays an imprtortant part to comprehend students understanding about learning material. Also, Reading is the main skill to interprete the meaning and purpose of learning material. Without reading, students cannot get what they want to learn. In every English teaching and learning activity, reading is used by students in the first step of learning. Students cannot write and speak if they do not read and comprehend the text. It can be stated that reading is very usefull in upgrading knowledge and the first step in mastering other skills.

Besides, students cannot comprehend the text if they have low understanding in several processes. Students should focus on the processes to create their capability in interpreting the meaning and catching the information from the text. The processes in reading comprehension can be defined as an advance reading which involved students' background knowledge, vocabulary mastery, concentration, grammar mastery. The processes above are the core design for students to be easy in understanding what they read. It can bring them to be a good and fast reader. Mikulecky and Jeffries (1996:1) stated that reading has some advantages and improving general language skills in English. Reading can help you to develop your ideas, facts and experiences, improving writing skill, and enlarging English vocabulary.

When the students focus on the text, they should determine their purpose in reading. The purpose will direct the students to the point of learning. In teaching and learning for accounting and finance and banking major in Economic College of Riau in year 2017-2018, the purposes in learning English are stated that students must be able to find the main idea of the text. Students must be able to find the interpretation of the text such as textual explicit, textual implicit and implicit only. The last, students must be able to develop their English vocabularies to be adopted in finance and banking activities. Based on the observation, students' are still difficult to interprete the reading text meanwhile they have read the text in several times. They canot find the appropriate meaning in some words related to finance and banking or accounting science. They are lack of vocabularies. Sometimes, students cannot get the information, meaning, and interpret the text because they cannot understand the vocabulary instruction. The definition of words is different in some contexts of science. It makes students difficult to arrange and comprehend the text. 
In order to make students' can comprehend the text, lecturer must be focused on how students enlarge the vocabulary by using effective vocabulary instruction in a long term comprehensive. Also, lecturer must give them more accounting and finance and banking text to develop their vocabulary. Then, lecturer must creative in using reading strategy. Therefore, an appropriate vocabulary instruction must be placed in the right discipline.

In case of achieving students reading comprehension, students should enlarge their vocabularies. Vocabulary can be defined as a list of words in a language which understood and memorized. Vocabulary supports students to get the knowledge about a text. They cannot interpret the text without understand the translation or meaning of words in the text. Ulfatussarifah (2017:209) argued that vocabulary is a collection of words in a language and it has function to create information, meaning, form and usage in context of communication.

Moreover, teaching and learning vocabulary to achieve students' reading comprehension must be in long term comprehensive approach. Effective vocabulary instruction should be in long term proposition. To create a long term effective vocabulary instruction, Nagy (2005:28) stated that students must focus on individual words, extensive exposure to rich language, oral and written activity, and building generative word knowledge. Therefore, students' reading comprehension to achieve teaching and learning purpose should be measured well with effective vocabulary instruction. In this research, writer intends to measure the correlation between vocabulary mastery and students' reading comprehension.

\section{RESEARCH METHOD}

This research was quantitative research method. It was designed by using correlation research. There were two variables measured in this research. The independent variable $(\mathrm{X})$ was vocabulary mastery and the dependent variable $(\mathrm{Y})$ was reading comprehension. This research used students in $4^{\text {th }}$ semester (academic year 2017-2018) at Economic College of Riau especially in Accounting and Finance and Banking major. There were 26 students as subject of the research. This research took all the students to be sample because the total number of students was small. There were two instruments used to collect the data. The instrument to measured vocabulary mastery was test. There were 25 questions given to the students. The questions related to the multiple choice completion, multiple choice paraphrases, and simple completion. In collecting the data of reading comprehension, the writer used test. There were 25 questions given to the students. The type of test was multiple choices. Students must 
answer the questions based on the suitable main idea, supporting details, and interpreting the meaning of text. This research used correlation statistical formula to analyze the data. It was computed by SPSS

\section{FINDING AND DISCUSSION}

This research computed by SPSS version 20 to calculate the research finding. After analyzing the data, the result describes below:

1. The Result of Vocabulary Mastery

Table 1 . The result of vocabulary mastery

\begin{tabular}{lllll}
\hline No & Categories & Score & Frequency & percentage \\
\hline 1 & Very good & $60-80$ & 24 & $92.3 \%$ \\
\hline 2 & Good & $40-59$ & 2 & $7.7 \%$ \\
\hline 3 & Enough & $20-39$ & 0 & $0 \%$ \\
\hline 4 & Low & $<20$ & 0 & $0 \%$ \\
\hline total & & & 26 & $100 \%$ \\
\hline
\end{tabular}

Based on the table above, there are 24 students in very good category and the percentage of this category is $92.3 \%$. There are 2 students in good category and the percentage of this category is $7.7 \%$. Meanwhile, there is no student in enough and low category and the percentage of these categories are $0 \%$. So, it can be concluded that the students' vocabulary mastery is in very good category.

Table 2. The result of reading comprehension

\begin{tabular}{lllll}
\hline No & Categories & Score & Frequency & Percentage \\
\hline 1 & Very good & $60-80$ & 3 & $11.5 \%$ \\
\hline 2 & Good & $40-59$ & 23 & $88.5 \%$ \\
\hline 3 & Enough & $20-39$ & 0 & $\%$ \\
\hline 4 & Low & $<20$ & 0 & $\%$ \\
\hline total & & & 26 & $100 \%$ \\
\hline
\end{tabular}

Based on the data above, the students are in very good category is 3 students and the percentage of this category is $11.5 \%$. The students are in good category is 23 students and the percentage of this category is $88.5 \%$. It can be say that the students' reading comprehension classified in good category. 
Table 3. The result of correlation between vocabulary and reading comprehension

\begin{tabular}{llll}
\hline & & vocabulary_mastery & reading_compreension \\
\hline \multirow{3}{*}{ vocabulary_mastery } & Pearson Correlation & 1 & -.083 \\
\cline { 2 - 4 } & Sig. (2-tailed) & 26 & .687 \\
\cline { 2 - 4 } & $\mathrm{N}$ & -.083 & 26 \\
\hline \multirow{3}{*}{ reading_compreension } & Pearson Correlation & .687 & 1 \\
\cline { 2 - 4 } & Sig. (2-tailed) & 26 & 26 \\
\cline { 2 - 4 } & $\mathrm{N}$ & & 26 \\
\hline
\end{tabular}

The table above describes that there is no correlation between vocabulary mastery toward their reading comprehension. It can be summarize from the table that, in the significant of pearson correlation, there is no correlation between variables. From table of product moment, it is stated that the significant correlation in $1 \%$ is 0.388 and the significant correlation in $5 \%$ is 0.496 . When it is compared to the table above, there is no indicating to significant $1 \%$ or $5 \%$. It is clear that vocabulary mastery do not give positive correlation to students' reading comprehension at Economic College of Riau.

\section{CONCLUSION}

Reading is an activity which helps people to understand the meaning and information. In this case, vocabulary is one of the factors influence people to get their comprehension in reading. Statistically, in facts, this research shows there is no correlation between vocabulary and reading comprehension. The finding in this research clearly stated that vocabularies do not give positive correlation to reading comprehension. In this research can give suggestion that, there are others factors influence reading comprehension and it need others further research for the future in finding the factors which has correlation to students reading comprehension at Economic College of Riau.

\section{BIBLIOGRAPHY}

Bishry, Hasanul. 2012. The Effect of Speed Reading Strategy to Improve Students' Reading Comprehension at the Second Year Students of State Senior High School 1 Dabo Singkep Regency of Lingga. Unpublished Thesis. UIN SUSKA Riau.

Day, R. Richard \& Park, Suk Jeong. 2005. Developing Reading Comprehension Questions. Journal of Reading in a Foreign Language. Vol.17, No. 1

Furqon, Fajar. 2013. Correlation between Students' Vocabulary Mastery and Their Reading Comprehension. Journal of English Education Vol. 1. Issue 1. 
Hiebert, H. Elbrida \& Kamil, L. Michael. 2005. Teaching and Learning Vocabulary: Bringing Research to Practice. London: Lawrence Erlbaum Associates Publisher

Klingner, Jannete, K, \& Sharon Vaughn \& Alison Boardman, (2007). Teaching Reading Comprehension to Students with Learning Difficulties [electronic book] New York: The Guilford Press.

Lehr, Fran., Osborn, Jean \& Hiebert, H. Elbrida. 2004. A Focus on Vocabulary. USA :PREL

Mikulecky, S. Batrice \& Jefries, Linda. 1996. More Reading Power. USA: Addison-Wesley Publishing Company

Nagy, William. 2005. Why Vocabulary Instruction Needs to Be Long-Term and Comprehensive. London: Lawrence Erlbaum Associates Publisher

Ulfatussyarifah. 2017. The Effects of Vocabulary and Grammar Mastery Toward Students Reading Comprehension of Grade X of State Senior High School Students in West Jakarta. Journal of English Language teaching Vol. 01, Issue 02, March 2017

Vaughn, Sharon \& Thompson, L. Sylvia. 2004. Research Based Methods of Reading Instruction Grade K-3. USA: Association for Supervision and Curriculum Development

Vinsja, P. Takac. 2008. Vocabulary Learning Strategies and Foreign Language Acquisition. UK: Multilingual Matters. 